\title{
PENGARUH SUHU TINGGI TERHADAP LENDUTAN DAN KEKAKUAN BALOK BETON BERTULANG
}

\author{
Faizin $^{1}$, Edhi Wahjuni Setyowati ${ }^{2}$, Wisnumurti $^{2}$ \\ ${ }^{1}$ Mahasiswa / Program Magister / Jurusan Teknik Sipil / Fakultas Teknik / \\ Universitas Brawijaya \\ ${ }^{2}$ Dosen / Jurusan Teknik Sipil / Fakultas Teknik / Universitas Brawijaya \\ Jalan Mayjend Haryono 167 Malang 65145 Indonesia \\ Korespondensi: faizindoank@yahoo.com
}

\begin{abstract}
The exposure of high temperatures which exposed reinforced concrete beams will cause damage to the cement paste as a binding component of the materials and decrease the ability of the beam. The objective of the study is to identify the high temperatures effect which exposed reinforced concrete beams (10 $\times 15 \times 100$ $\mathrm{cm})$, focusing on the bending stiffness, deflection and bending capacity. The tests were conducted in some temperature variations which are $400{ }^{\circ} \mathrm{C}, 600{ }^{\circ} \mathrm{C}$ and $800{ }^{\circ} \mathrm{C}$ with the heating concept based on the slow changes of surface temperature and the convective heat transfer, the normal beam specimens $\left(27^{\circ} \mathrm{C}\right)$ were also tested as control specimens. The results show that the bending capacity decreases as the heating temperature increases, followed by the decrease of bending stiffness and also the increase of deflection before the beam reaches the first yield, then there is an increase on the bending stiffness of the beam which have been exposed by high temperature at $400{ }^{\circ} \mathrm{C}$ after the first yield is reached.
\end{abstract}

Keywords: bending capacity, bending stiffness, deflection, high temperatures

\section{PENDAHULUAN}

Secara umum struktur beton bertulang tidak dikhususkan untuk menghadapi suhu yang tinggi, namun dalam beberapa kasus struktur beton bertulang akan mengalami paparan suhu tinggi seperti akibat peristiwa kebakaran. Kebakaran dapat terjadi karena adanya reaksi oksidasi antara oksigen dan bahan bakar saat segitiga api mengalami keseimbangan, panas yang dihasilkan oleh kebakaran akan disebarkan secara radiasi, konduksi dan konveksi. Pemanasan yang dialami oleh beton menyebabkan terjadinya perubahan sifat senyawa hasil hidrasi, $\mathrm{CH}$ (calcium hydroxide) serta C-S-H (calcium silicate hydrate) merupakan senyawa hasil hidrasi semen yang akan mengalami proses dekomposisi serta dehidrasi pada suhu $400{ }^{\circ} \mathrm{C}$ dan menghasilkan $\mathrm{CaO}$ (calcium oxide) yang mempunyai ketahanan relatif rendah pada suhu tinggi.

Paparan suhu tinggi yang dialami oleh balok beton bertulang akan mengakibatkan fasa portlandite pada semen berkurang dan membuat pasta semen kehilangan sifatnya sebagai bahan pengikat antar material balok beton bertulang [1]. Pengaruh suhu tinggi juga dapat mengakibatkan pasta semen mengalami dehidrasi dan membawa pada penurunan kekuatan pasta semen sebagai bahan pengikat antar material [2].

$$
\begin{aligned}
& \mathrm{CaO} \cdot \mathrm{SiO}_{2} \cdot \mathrm{H}_{2} \mathrm{O} \rightarrow \mathrm{CaO}+\mathrm{SiO}_{2}+\mathrm{H}_{2} \mathrm{O} \uparrow \\
& \mathrm{CaO} \cdot \mathrm{H}_{2} \mathrm{O} \rightarrow \mathrm{CaO}+\mathrm{H}_{2} \mathrm{O} \uparrow
\end{aligned}
$$

Produk dominan berupa senyawa $\mathrm{CH}$ dan C-S$\mathrm{H}$ akan dihasilkan selama masa hidrasi beton, penambahan pozzolan menyebabkan terjadinya reaksi antara pozzolan dengan $\mathrm{CH}$ dan menghasilkan senyawa C-S-H baru sehingga membuat beton mempunyai nilai kekuatan lebih tinggi dan relatif tahan pada perubahan suhu tinggi [3].

$$
\begin{aligned}
& \left(\mathrm{C}_{3} \mathrm{~S}+\cdots\right)+\mathrm{H}_{2} \mathrm{O} \stackrel{\text { cepat }}{\longrightarrow} \mathrm{C}-\mathrm{S}-\mathrm{H}+\mathrm{CH} \\
& \text { Pozzolan }+\mathrm{CH}+\mathrm{H}_{2} \mathrm{O} \stackrel{\text { lambat }}{\longrightarrow} \mathrm{C}-\mathrm{S}-\mathrm{H}
\end{aligned}
$$

Paparan suhu tinggi pada balok beton bertulang juga dapat mengakibatkan baja 
tulangan mengalami penurunan kekuatan tarik, penurunan kekuatan tarik ini akan terjadi saat baja tulangan mendapatkan pengaruh suhu tinggi, tetapi kekuatan tarik akan mengalami peningkatan kembali saat baja tulangan dingin meskipun tidak terjadi sepenuhnya. Kekuatan sisa baja tulangan jenis hot rolled dan cold worked yang telah mengalami pemanasan pada suhu $600{ }^{\circ} \mathrm{C}$ hanya menunjukkan penurunan kekuatan sebesar $10 \%-15 \%$ meskipun regangan ultimate mengalami kenaikan sebesar $50 \%$ pada jenis hot rolled dan $150 \%$ pada jenis cold worked [4].

Penurunan kekuatan yang terjadi pada beton dan baja tulangan akan menyebabkan balok beton bertulang mengalami reduksi kemampuan dalam menerima pembebanan yang diberikan, disamping itu pemanasan yang telah dialami balok beton bertulang juga dapat menyebabkan retak pada zona transisi antara agregat dan pasta semen mengalami peningkatan akibat perbedaan angka muai antar material, peningkatan retak pada zona transisi ini mengakibatkan retak lentur yang terjadi akibat pembebanan semakin mudah terbentuk dan membuat balok cenderung lebih mudah mengalami perubahan penampang dari tidak retak menjadi retak.

Perubahan penampang balok dari tidak retak menjadi retak yang semakin mudah terjadi dapat menandakan kekakuan lentur balok yang merupakan fungsi dari momen inersia dan modulus elastisitas mengalami penurunan. Pada balok beton bertulang, kedua variabel tersebut akan mengalami perubahan selama proses pembebanan yang dilakukan, variasi pada modulus elastisitas disebabkan oleh perilaku tegangan dan regangan inelastis dari beton yang telah melebihi batas elastisnya, sedangkan variasi yang terjadi dalam momen inersia sangat dipengaruhi oleh retak yang terjadi pada balok [5].

Penurunan kekakuan lentur balok yang terjadi setelah balok mengalami pemanasan pada suhu tinggi akan mengakibatkan nilai lendutan balok mengalami peningkatan, hal ini dikarenakan kekakuan lentur merupakan variabel penting dalam membatasi lendutan yang terjadi. Penurunan kekakuan lentur balok akan menyebabkan perubahan sumbu penampang balok menjadi lengkung akibat pembebanan mengalami peningkatan dan membuat perpindahan dari setiap titik yang terjadi pada bentang balok beton bertulang juga mengalami peningkatan [6].

Dengan konsep pemanasan benda uji yang didasarkan pada perubahan suhu yang lambat dan penyebaran panas terjadi secara konveksi. Penelitian ini bertujuan untuk mengidentifikasi kekakuan lentur, lendutan serta kapasitas lentur balok yang telah mengalami pemanasan pada suhu tinggi dengan balok normal sebagai pembanding.

\section{METODOLOGI PENELITIAN}

Penelitian dilaksanakan dengan metode eksperimental di Laboratorium. Beton yang digunakan dalam penelitian didapatkan dari campuran semen PPC dengan agregat kasar batu pecah ukuran maksimum $20 \mathrm{~mm}$ dan agregat halus pasir sungai dengan ukuran maksimum 4,8 mm. Beton dibuat dengan mutu rencana 35 Mpa pada umur 28 hari.

Penulangan utama balok menggunakan baja tulangan ulir dengan rerata: diameter aktual 9,42 mm, tegangan leleh 394,1 Mpa dan tegangan putus 557,6 Mpa. Penulangan geser balok menggunakan tulangan polos dengan rerata: diameter aktual sebesar 5,79 $\mathrm{mm}$ dan tegangan leleh sebesar 313,4 Mpa.

Benda uji silinder beton untuk uji kuat tekan dibuat sebanyak 20 buah untuk setiap variasi suhu pemanasan dengan dimensi silinder $15 \times 30 \mathrm{~cm}$. Benda uji balok beton bertulang untuk uji lentur dibuat sebanyak 3 buah untuk setiap variasi suhu pemanasan dengan dimensi balok 10 × 15 x $100 \mathrm{~cm}$, selimut beton untuk balok beton bertulang digunakan sebesar $2 \mathrm{~cm}$. 


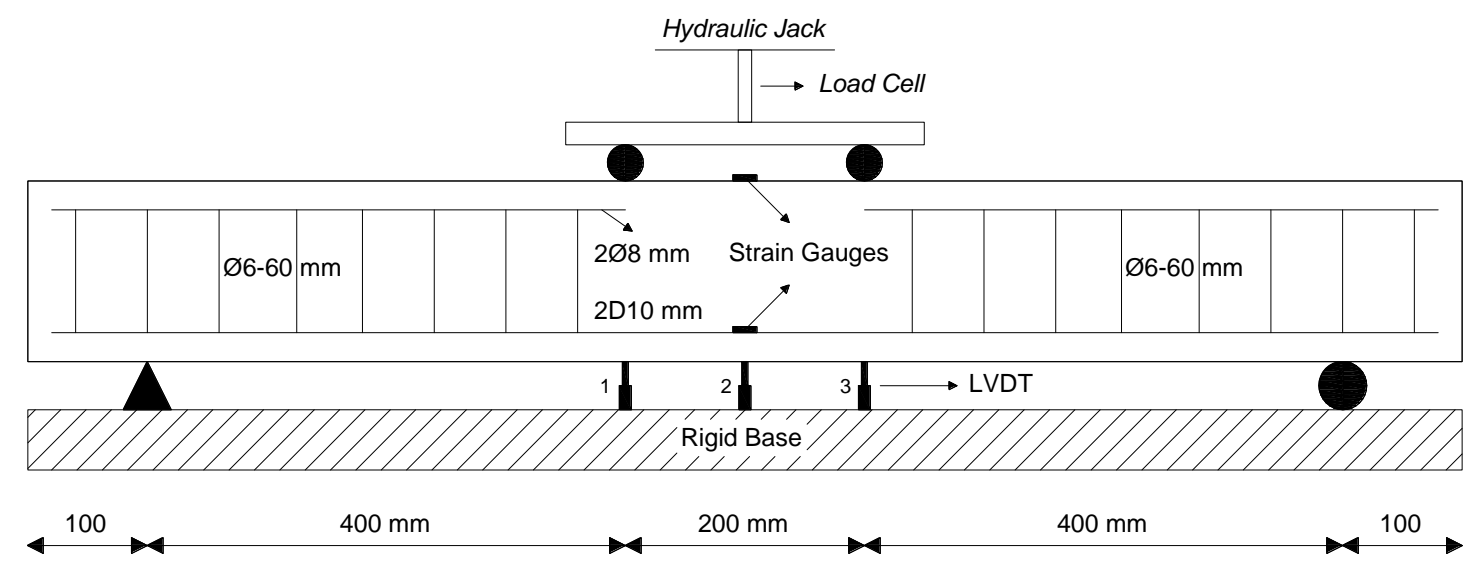

Gambar 1. Detail penulangan dan pengujian lentur balok beton bertulang

Pemanasan untuk setiap variasi benda uji dilakukan dengan tungku jenis sirkulasi panas berbalik atau down draft kiln dengan kecepatan pemanasan sebesar $\pm 125^{\circ} \mathrm{C} / \mathrm{Jam}$. Pengukuran suhu di dalam tungku pemanas menggunakan Thermocouple dengan suhu maksimum yang dapat terukur pada alat sebesar $1200^{\circ} \mathrm{C}$.

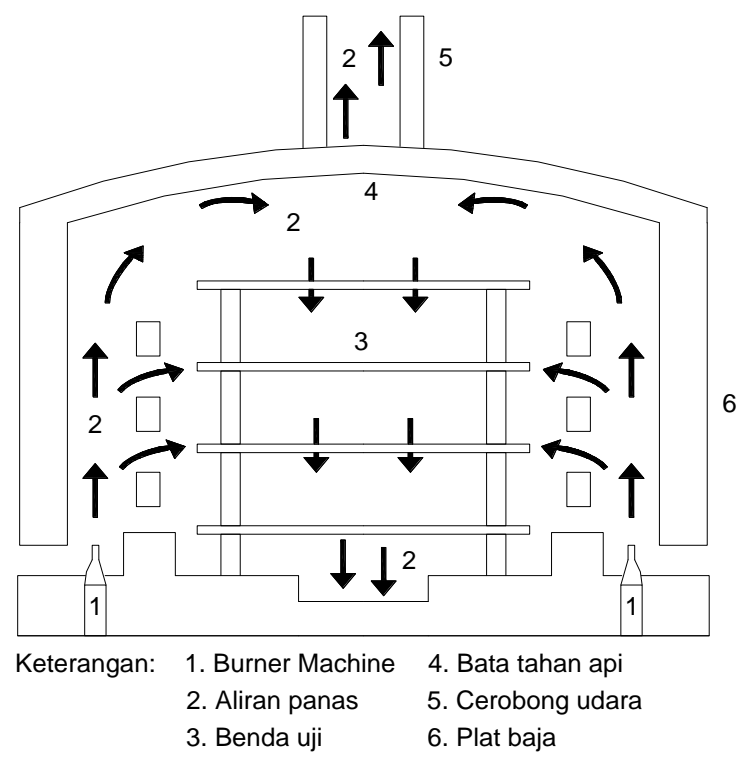

Gambar 2. Tungku untuk proses pemanasan benda uji

Benda uji yang telah mendapatkan pemanasan akan dibiarkan dingin terlebih dahulu di dalam tungku selama satu hari sebelum dikeluarkan dan tungku digunakan kembali untuk proses pemanasan benda uji selanjutnya, proses pemanasan benda uji serta proses pendinginan dilakukan secara berulang untuk setiap variasi suhu yang digunakan (400 ${ }^{\circ} \mathrm{C}, 600{ }^{\circ} \mathrm{C}$ dan $800{ }^{\circ} \mathrm{C}$ ).

\section{HASIL DAN PEMBAHASAN}

Dari proses pemanasan yang dilakukan pada setiap benda uji, didapatkan besarnya nilai pertambahan suhu di dalam tungku pemanas yang terukur pada Thermocouple seperti yang terlihat pada Gambar 3 .

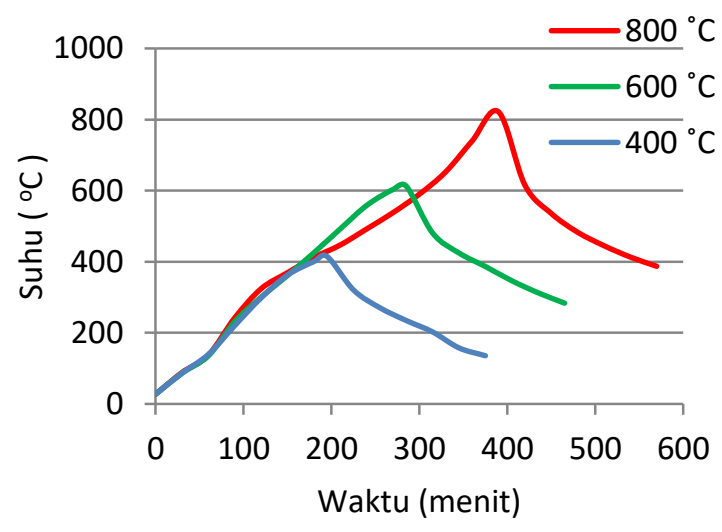

Gambar 3. Perubahan suhu di dalam tungku saat pemanasan dan pendinginan

Besarnya kenaikan suhu untuk setiap proses pemanasan benda uji yang dilakukan mempunyai kecepatan yang relatif sama untuk setiap variasi suhu pemanasan yang digunakan, begitu juga dengan besarnya penurunan suhu selama proses pendinginan benda uji, pengukuran suhu selama proses pendinginan tidak dilakukan sampai suhu ruang atau sampai pada suhu $27^{\circ} \mathrm{C}$, tetapi hanya dilakukan selama 
180 menit dari saat sumber api tungku pemanas dimatikan.

Pengukuran besarnya suhu bertujuan untuk memastikan bahwa setiap benda uji mempunyai pola pertambahan suhu dan juga pola penurunan suhu yang sama pada setiap proses pemanasan dan pendinginan benda uji yang dilakukan.

\subsection{Kuat tekan beton}

Benda uji silinder beton umur 45 hari, baik silinder normal (SN) maupun silinder yang telah mendapatkan pemanasan pada suhu tinggi (SB1, SB2, SB3) menghasilkan rerata kuat tekan beton seperti yang terlihat dalam Tabel 1.

Tabel 1. Kuat tekan rata-rata silinder beton

\begin{tabular}{ccccc}
\hline \multirow{2}{*}{$\begin{array}{c}\text { Benda } \\
\text { Uji }\end{array}$} & \multicolumn{2}{c}{$\begin{array}{c}\text { Berat Silinder } \\
(\mathrm{kg})\end{array}$} & \multirow{2}{*}{$\begin{array}{c}\text { Suhu } \\
\left({ }^{\circ} \mathrm{C}\right)\end{array}$} & $\begin{array}{c}\text { Kuat } \\
\text { Tekan } \\
(\mathrm{Mpa})\end{array}$ \\
\cline { 2 - 3 } & Before & After & & \\
\hline SN* & 12,51 & 12,51 & 27 & 42,24 \\
\hline SB1 & 12,56 & 11,49 & 400 & 27,65 \\
\hline SB2 & 12,54 & 11,68 & 600 & 25,68 \\
\hline SB3 & 12,52 & 11,32 & 800 & 18,51 \\
\hline
\end{tabular}

* Silinder normal, tanpa pemanasan

Tabel 1 memperlihatkan bahwa nilai kuat tekan silinder beton akan mengalami penurunan semakin besar seiring dengan bertambahnya suhu pemanasan, penurunan kuat tekan terhadap silinder kontrol terjadi secara berturut sebesar $34,5 \% ; 39,2 \%$ dan $56,1 \%$ setelah benda uji silinder mengalami pemanasan pada suhu $400{ }^{\circ} \mathrm{C}, 600{ }^{\circ} \mathrm{C}$ dan 800 ${ }^{\circ} \mathrm{C}$. Proses dehidrasi serta dekomposisi pada senyawa $\mathrm{CH}$ dan $\mathrm{C}-\mathrm{S}-\mathrm{H}$ menyebabkan pasta semen kehilangan karakteristiknya sebagai bahan pengikat material penyusun beton [2] dan membawa pada penurunan kemampuan dari beton itu sendiri.

\subsection{Kapasitas lentur penampang balok}

Dari hasil pengujian lentur balok beton bertulang didapatkan besarnya rerata beban yang mengakibatkan balok retak pertama (Pcr), leleh pertama (Py) dan juga besarnya beban maksimum $(\mathrm{Pu})$ yang dapat diterima balok untuk setiap variasi suhu pemanasan seperti yang terlihat dalam Tabel 2.
Tabel 2. Kapasitas lentur penampang balok beton bertulang

\begin{tabular}{ccccc}
\hline $\begin{array}{c}\text { Benda } \\
\text { Uji }\end{array}$ & $\begin{array}{c}\text { Suhu } \\
\left({ }^{\circ} \mathrm{C}\right)\end{array}$ & $\begin{array}{c}\mathrm{P}_{\text {cr }} \\
(\mathrm{kg})\end{array}$ & $\begin{array}{c}\mathrm{P}_{\mathrm{y}} \\
(\mathrm{kg})\end{array}$ & $\begin{array}{c}\mathrm{P}_{\mathrm{u}} \\
(\mathrm{kg})\end{array}$ \\
\hline BN* & 27 & 833,3 & 2933,3 & 3800,0 \\
\hline BB1 & 400 & 633,3 & 2633,3 & 3566,7 \\
\hline BB2 & 600 & 500,0 & 2433,3 & 3200,0 \\
\hline BB3 & 800 & 400,0 & 2433,3 & 3100,0 \\
\hline * Balok normal, tanpa pemanasan
\end{tabular}

Tabel 2 memperlihatkan bahwa balok beton bertulang yang yang telah mengalami pemanasan pada $400{ }^{\circ} \mathrm{C}, 600{ }^{\circ} \mathrm{C}$ dan $800{ }^{\circ} \mathrm{C}$ (BB1, BB2, BB3) mengalami penurunan secara berturut nilai beban terhadap balok normal (BN) atau balok kontrol sebesar 24,0\%;39,9\% dan $51,9 \%$ untuk besarnya beban retak pertama, kemudian sebesar 10,2\%; 17,0\% dan $17,0 \%$ untuk besarnya beban leleh pertama, kemudian sebesar $6,1 \% ; 15,7 \%$ dan $18,4 \%$ untuk besarnya beban maksimum.

Reduksi nilai kuat tekan dan kuat tarik yang terjadi pada beton serta peningkatan intensitas retak pada zona transisi antara agregat dengan pasta semen akan membuat balok beton bertulang mengalami reduksi besarnya nilai beban yang mengakibatkan balok retak pertama, leleh pertama maupun besarnya beban maksimum, disamping itu penurunan kuat tarik yang terjadi pada baja tulangan [4] juga akan mengakibatkan nilai kapasitas lentur penampang untuk balok yang telah mendapatkan pengaruh suhu tinggi mengalami penurunan.

\subsection{Lendutan dan kekakuan balok}

Dari pengujian lentur balok didapatkan besarnya nilai lendutan balok yang terjadi pada daerah respons maksimum atau pada tengah bentang balok, nilai rerata lendutan untuk variasi balok beton bertulang normal (BN) maupun balok beton bertulang yang telah mendapatkan pengaruh suhu tinggi pada $400{ }^{\circ} \mathrm{C}$ (BB1), $600{ }^{\circ} \mathrm{C}(\mathrm{BB} 2)$ dan juga $800{ }^{\circ} \mathrm{C}$ (BB3) dapat dilihat melalui kurva hubungan beban lendutan balok seperti yang telihat dalam Gambar 4. 


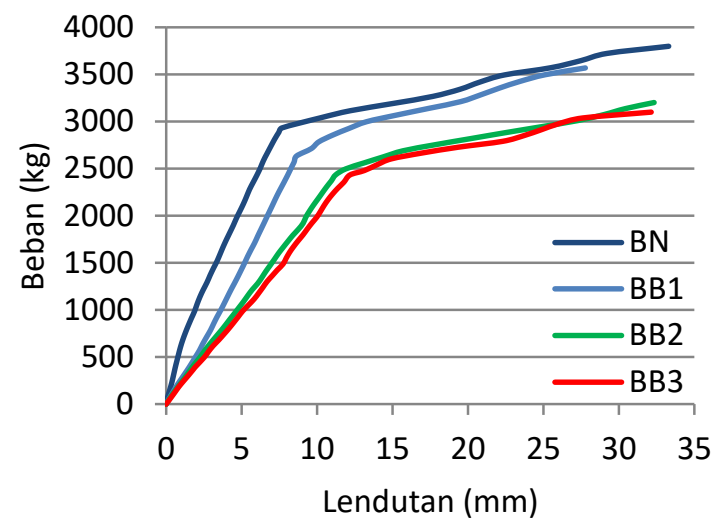

Gambar 4. Hubungan beban dengan lendutan balok beton bertulang

Dari Gambar 4 dapat terlihat adanya kecenderungan dalam penurunan kekakuan lentur balok yang disertai peningkatan nilai lendutan balok, hal ini dapat dilihat melalui kemiringan kurva hubungan beban dengan lendutan yang semakin landai setelah balok mengalami pemanasan (BB1, BB2, BB3). Bentuk kurva juga mengalami perubahan dari trilinear menjadi bilinear setelah balok mendapatkan pemanasan pada suhu $400{ }^{\circ} \mathrm{C}$, $600{ }^{\circ} \mathrm{C}$ dan $800{ }^{\circ} \mathrm{C}$ (BB1, BB2 dan BB3).

Kecenderungan dalam penurunan nilai kekakuan yang disertai dengan peningkatan nilai lendutan terjadi sampai leleh pertama balok, setelah leleh pertama balok tercapai nilai kekakuan lentur mengalami sedikit peningkatan untuk variasi suhu pemanasan $400{ }^{\circ} \mathrm{C}$ terhadap balok normal seperti yang terlihat pada kurva hubungan beban dengan lendutan balok pada Gambar 4, hal ini bisa disebabkan karena perubahan dari struktur mikro beton yang menjadi semakin padat atau menjadi semakin massif [1].

Anomali yang terjadi pada suhu $400{ }^{\circ} \mathrm{C}$ dapat disebabkan karena $400{ }^{\circ} \mathrm{C}$ merupakan suhu kritis dimana senyawa-senyawa dalam pasta semen mulai mengalami perubahan sifat kimianya, perubahan sifat kimia pasta semen ini dapat membawa pada penurunan kekuatan beton atau dapat membuat beton mengalami peningkatan kekuatan, terlebih pada beton dengan kandungan silika yang cukup tinggi $[1,7]$.

Dari kurva hubungan beban - lendutan balok bisa didapatkan besarnya kekakuan lentur benda uji balok seperti yang terlihat dalam Gambar 5.

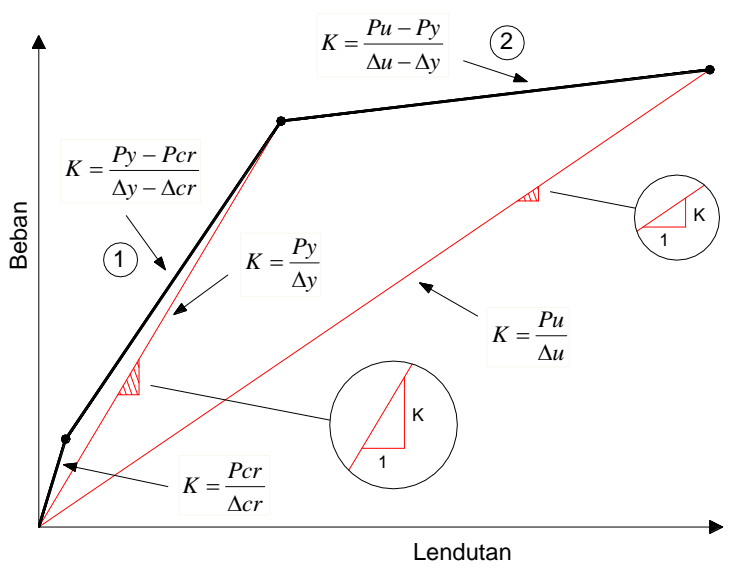

Gambar 5. Hubungan antara beban, lendutan dan kekakuan lentur balok

Kekakuan lentur aktual balok sebelum leleh dalam Gambar 5 dinotasikan dengan angka (1). Kekakuan lentur aktual balok setelah leleh dinotasikan dengan angka (2).

Besarnya lendutan balok yang terjadi saat balok retak pertama, leleh pertama dan saat beban maksimum balok tercapai dapat dilihat pada Tabel 3.

Tabel 3. Lendutan $(\Delta)$ balok beton bertulang

\begin{tabular}{cccc}
\hline $\begin{array}{c}\text { Keadaan } \\
\text { Balok }\end{array}$ & $\begin{array}{c}\text { Benda } \\
\text { Uji }\end{array}$ & $\begin{array}{c}\text { Suhu } \\
\left({ }^{\circ} \mathrm{C}\right)\end{array}$ & $\begin{array}{c}\Delta \\
(\mathrm{mm})\end{array}$ \\
\hline \multirow{3}{*}{$\begin{array}{c}\text { First Crack } \\
(\Delta \mathrm{cr})\end{array}$} & $\mathrm{BN}^{*}$ & 27 & 1,47 \\
\cline { 2 - 4 } & $\mathrm{BB} 1$ & 400 & 2,41 \\
\cline { 2 - 4 } & $\mathrm{BB} 2$ & 600 & 2,26 \\
\cline { 2 - 4 } & $\mathrm{BB} 3$ & 800 & 1,96 \\
\hline \multirow{2}{*}{$\begin{array}{c}\text { First Yield } \\
(\Delta \mathrm{y})\end{array}$} & $\mathrm{BN}^{*}$ & 27 & 7,68 \\
\cline { 2 - 4 } & $\mathrm{BB} 1$ & 400 & 8,65 \\
\cline { 2 - 4 } & $\mathrm{BB} 2$ & 600 & 11,24 \\
\hline \multirow{3}{*}{$\begin{array}{ccc}\text { Ultimate } \\
(\Delta \mathrm{u})\end{array}$} & $\mathrm{BB} 3$ & 800 & 12,19 \\
\cline { 2 - 4 } & $\mathrm{BB}{ }^{*}$ & 27 & 33,29 \\
\cline { 2 - 4 } & $\mathrm{BB} 2$ & 600 & 27,77 \\
\cline { 2 - 4 } & $\mathrm{BB} 3$ & 800 & 32,32 \\
\hline
\end{tabular}

* Balok normal, tanpa pemanasan

Besarnya kekakuan lentur balok beton bertulang pada saat balok belum leleh dan setelah leleh dapat dilihat pada Tabel 4. 
Tabel 4. Kekakuan lentur aktual (K) benda uji balok beton bertulang

\begin{tabular}{ccc}
\hline Keadaan Balok & $\begin{array}{c}\text { Benda } \\
\text { Uji }\end{array}$ & $\begin{array}{c}\mathrm{K} \\
(\mathrm{kg} / \mathrm{mm})\end{array}$ \\
\hline \multirow{2}{*}{ Pra Leleh } & $\mathrm{BN} *$ & 338,3 \\
\cline { 2 - 3 }$(1)$ & $\mathrm{BB} 1$ & 320,5 \\
\cline { 2 - 3 } & $\mathrm{BB} 2$ & 212,4 \\
\hline \multirow{2}{*}{ Pasca Leleh } & $\mathrm{BB} 3$ & 198,9 \\
$(2)$ & $\mathrm{BN} *$ & 33,8 \\
\hline & $\mathrm{BB} 1$ & 48,8 \\
\hline & $\mathrm{BB} 2$ & 36,4 \\
\hline
\end{tabular}

* Balok normal, tanpa pemanasan

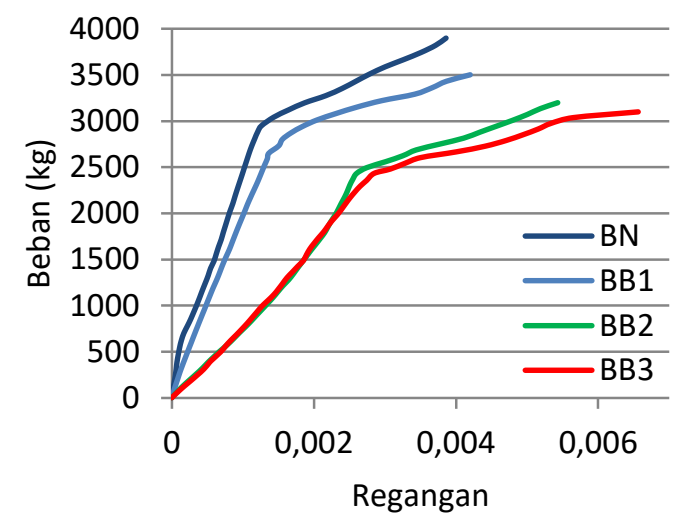

Gambar 6. Nilai regangan beton pada daerah serat tekan terluar balok

Dari pengujian lentur yang dilakukan pada balok, selain didapatkan hubungan beban lendutan juga didapatkan besarnya nilai regangan tekan beton pada serat tekan terluar balok beton bertulang atau pada daerah respons tegangan tekan maksimum pada balok beton bertulang seperti yang terlihat dalam Gambar 6.

Peningkatan nilai regangan beton pada serat tekan terluar balok dapat menandakan bahwa beton pada balok beton bertulang yang mendapatkan pemanasan (BB1, BB2 dan BB3) mengalami penurunan nilai kuat tekan, penurunan nilai kuat tekan beton ini mengakibatkan beton memiliki kemampuan meregang lebih besar dan akan hancur pada nilai regangan yang lebih tinggi dibanding dengan beton pada balok beton bertulang normal $(\mathrm{BN})$.

\section{KESIMPULAN}

Pengaruh suhu tinggi pada balok beton bertulang sangat dipengaruhi oleh banyak faktor, perbedaan material penyusun yang digunakan, dimensi benda uji serta proses pemanasan benda uji yang digunakan dapat memberikan hasil yang berbeda. Dari hasil analisis serta pembahasan yang dilakukan, dapat diperoleh kesimpulan dari penelitian sebagai berikut:

1. Kapasitas lentur balok beton bertulang mengalami penurunan semakin besar seiring dengan bertambahnya suhu yang dialami balok.

2. Nilai kekakuan lentur balok mengalami penurunan dengan disertai peningkatan nilai lendutan yang terjadi sampai leleh pertama balok untuk variasi balok yang telah mendapatkan pengaruh suhu tinggi terhadap balok normal.

3. Nilai kekakuan lentur balok mengalami peningkatan setelah leleh pertama balok tercapai untuk variasi balok yang telah mendapatkan pengaruh suhu tinggi pada $400{ }^{\circ} \mathrm{C}$ terhadap balok normal.

4. Penurunan kapasitas lentur penampang balok terbesar dialami oleh balok yang telah mendapatkan pengaruh suhu tinggi pada $800{ }^{\circ} \mathrm{C}$ dengan penurunan beban ultimate sebesar $18,42 \%$ dan kekakuan lentur sebesar $41,22 \%$ terhadap balok beton bertulang normal.

\section{DAFTAR PUSTAKA}

[1] Setyowati, E. W., Soehardjono, A., Wardana, I.

G. N. \& Irawan, Y. S. 2015. The Micro Crack Growth Behavior on the Post Fire Reinforced Concrete Beam. International Journal of Engineering and Technology. 7 (5): $1856-1861$.

[2] Lee, J., Xi, Y., Willam, K. \& Jung, Y. 2009. A Multiscale Model for Modulus of Elasticity of Concrete at High Temperatures. Cement and Concrete Research. 39 (2009): 754 762.

[3] Mehta, P. K. \& Monteiro, P. J. M. 2001. Concrete Microstructures, Properties and Materials. New Jersey: Prentice Hall.

[4] Elghazouli, A. Y., Cashell, K. A. \& Izzuddin, B. A. 2009. Experimental Evaluation of the Mechanical Properties of Steel Reinforcement at Elevated Temperature. Fire Safety Journal. 44 (2009): 909 - 919.

[5] Kalkan, I. 2013. Deflection Prediction for Reinforced Concrete Beams through 
Different Effective Moment of Inertia Expressions. International Journal of Engineering Research and Development. 5 (1): $1-9$.

[6] Gere, J. M. 2004. Mechanics of Materials $6^{\text {th }}$ Edition. Belmont: Thomson Learning.
[7] Lim, S. 2015. Effects of Elevated Temperature Exposure on Cement: Based Composite Materials. PhD Thesis. Unpublished. Urbana: University of Illinois. 